\title{
"Not just useless bush": food culture and spontaneous plants in the Jequitinhonha Valley, Minas Gerais/Brazil
}

\author{
Luiza Helena Pedra da Silva \\ Fabiane Nepomuceno Costa \\ Nadja Maria Gomes Murta
}

${ }^{\text {I }}$ Universidade Federal dos Vales do Jequitinhonha e Mucuri (UFVJM), Diamantina, MG, Brasil.

D II Universidade Federal dos Va les do Jequitinhonha e Mucuri (UFVJM), Diamantina, MG, Brasil.

Universidade Federal dos Vales do Jequitinhonha e Mucuri (UFVJM), Diamantina, MG, Brasil.

\begin{abstract}
Food knowledge and practices in the Jequitinhonha Valley are the result of its socio-biodiversity and suffer the impacts of the food homogenization process. This study aims to characterize the food social space and the role of spontaneous plant species in the community of São João da Chapada in Diamantina (Minas Gerais/Brazil) and thereby contribute to strengthening food culture in rural communities. With a qualitative and quantitative approach and participant observation, semi-structured interviews, ethno-botanical walks and culinary demonstrations were performed. Thematic content analysis and descriptive statistics show that the local food social space management is the work of women and has a strong territorial bond. 78 species of spontaneous food plants were identified. They play both nutritional and symbolic roles and are in the culinary culture albeit knowledge of them is greater than their effective use.
\end{abstract}

Keywords: Food social space; Socio-biodiversity; Non-conventional food plants; Ethnobotany; Food system.

São Paulo. Vol. 24, 2021

Original Article

DOI: http://dx.doi.org/10.1590/1809-4422asoc20210003r1vu2021L5AO 


\section{INTRODUCTION}

The human diet is constructed by a complex cultural system that classifies, attributes symbols and meanings and determines what can be eaten, structuring the foodrelated habits and behaviors. That system is referred to as food culture (BRAGA, 2004). The concept of a food social space refers to the zone of integration between the biological and cultural aspects of food and makes it clear that, in addition to the cultural aspect of food, there are also ecological, biological and physiological aspects involved (POU. LAIN; PROENÇA, 2003; POULAIN, 2004). From that broader perspective of food and feeding determinants, this study adopts the food social space as a tool to enable a better understanding of food culture.

Six aspects of the food social space will guide the organization of the results presented in this work, namely: food system - the food production chains engendered and activated by social and technological structures, ranging from cultivation and gathering to culinary preparation; culinary space - kitchens and their technical and symbolic aspects; eatables space - the set of choices among natural potentially edible substances that endows them with the status of food; food habits and consumption - social organization and rituals associated to the act of eating; food temporality - the relations of human food with the temporal cycles of a given culture; and food social differentiation - processes related to the establishment or validation of identity boundaries by means of food.

In a food social space, regional foods embody the results of historical processes of interaction between human cultures and the environment they live in. A variety among regional foods is related to the socio-biodiversity "a concept that expresses the inter-relation between biological diversity and the diversity of sociocultural systems" (BRASIL, 2009).

Outstanding among the regional foods and other linked to socio-biodiversity are those based on plants of little economic interest or value but with important traditional uses for various communities. There are various nomenclatures and subdivisions for those edible plants but currently they are widely known in Brazil by the acronym PANC which stands for Plantas Alimentícias Não Convencionais (Non-conventional food plants), a term coined by Kinupp (2007). This study adopts that nomenclature but with a critical reservation insofar as a set of 'non-conventional' plants presuppose the existence of another set of 'conventional' ones and that could jeopardize the recognition and valorization of food culture diversity.

Although the term PANC has been created to designate different neglected and under-utilized plants and contribute to fostering their consumption, the very author who created it acknowledges its limitations (KINUPP; LORENZI, 2014). Nevertheless, we adopt the acronym PANC in recognition of the objectives of its creation and to communicate with readers who presently identify the neglected plants with that acronym.

A considerable number of the PANC species are considered to be 'spontaneous', that is, "[...] they grow without any human care or cultivation, and they include native (autochthon) species as much as naturalized ones [...]" (SCHNEIDER, 2007). These plants, especially those with a herbaceous habit are popularly known in Brazil as inços, daninhas and ruderais, that is, weeds. 
This study aims to identify and analyze the relationship between a food culture and spontaneous plants by means of the food social space of the São João da Chapada community in the municipality of Diamantina (State of Minas Gerais, Brazil). The decision to focus on spontaneous plant species was made because they have some comparative advantages over cultivated plants with lesser demand for agricultural inputs, arable land and labor. Furthermore, the proposal takes into account the scarcity of scientific production addressing these spontaneous species.

For analysis purposes we consider food categories based on the kind of processing, in keeping with the proposal of the Food Guide for the Brazilian Population (Guia Alimentar para a População Brasileira) (BRASIL, 2014). The food plants belong to the categories: food in natura, extracted directly from plants, animals or fungi without being altered in any way; and minimally processed food, (food in natura that has undergone minimal alteration). According to the Brazilian Ministry of Health, those two groups of food should constitute the base of people's food consumption (BRASIL, 2014). The other categories contemplated by the Guide are: fats, oils, salt and sugar (processed culinary ingredients) which should only be consumed in moderation; processed food, (food produced with added salt, sugar or other substances to enhance flavor or durability) also to be consumed with moderation, and ultra-processed food, (industrialized food produced using substances extracted from food or synthesized in laboratories), which should be avoided (BRASIL, 2014; MONTEIRO et al., 2016).

\section{MATERIAL AND METHODS}

\subsection{Study area}

The district of São João da Chapada, which local people call simply São João, is located in the rural zone of the municipality of Diamantina (Figure 1), in the upper part of the Jequitinhonha valley which since the 1960s has been nationally notorious for its very low socioeconomic indicators (RIBEIRO et al., 2014), but which, at the same time is a site of vast sociocultural wealth. The Diamantina region is known for its natural attributes being part of the Espinhaço Range Biosphere Reserve which has a high level of biodiversity, endemism and biological vulnerability (IABS; RBSE, 2017; BRASIL, [2005?]). 
Figure 1 - Location of São João da Chapada (Minas Gerais/Brazil)
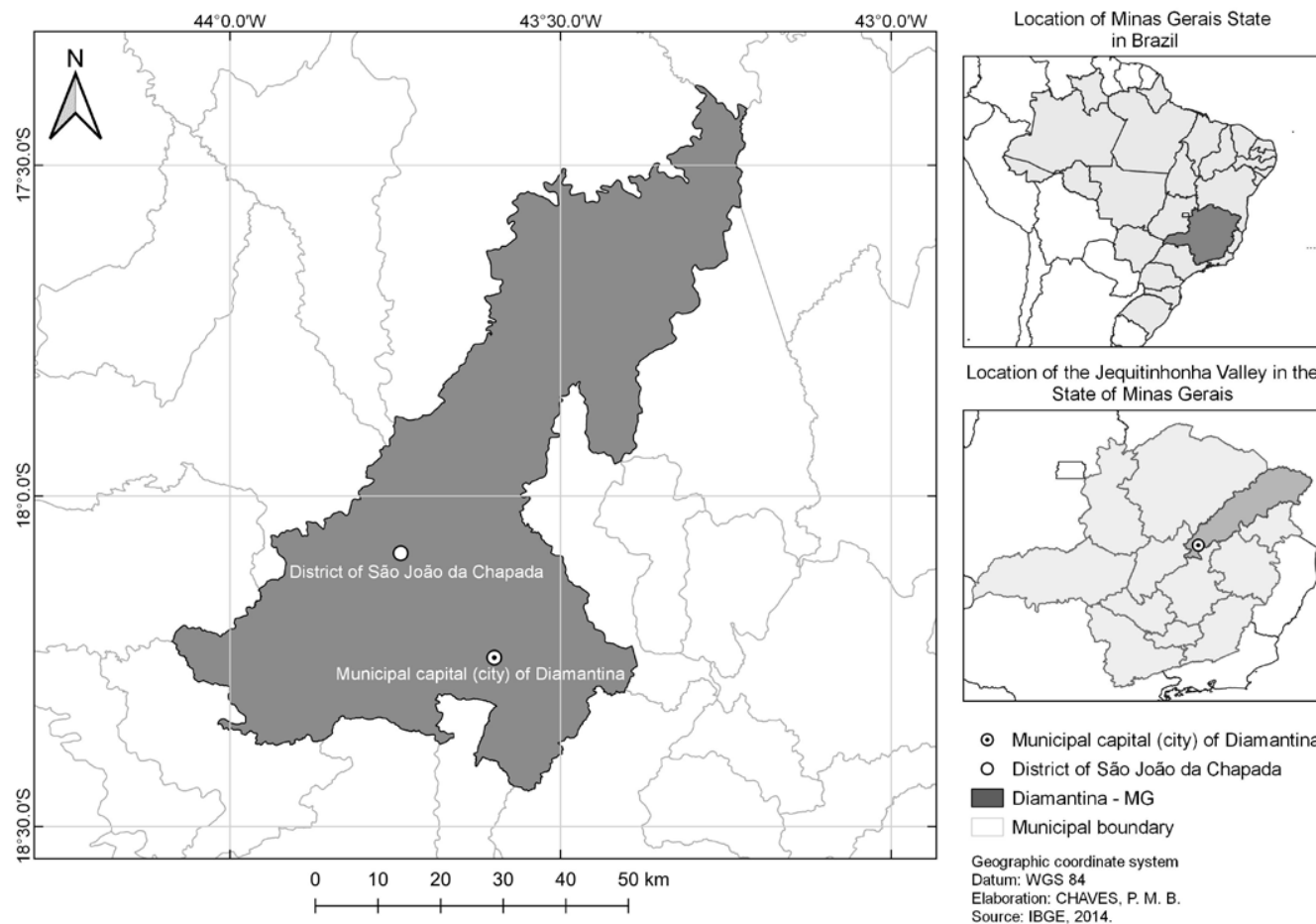

Location of the Jequitinhonha Valley in the State of Minas Gerais

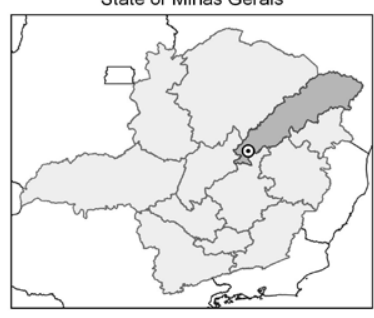

○ Municipal capital (city) of Diamantina

○ District of São João da Chapada

$\square$ Diamantina - MG

Municipal boundary

Geographic coordinate system Datum: WGS 84

Elaboration: CHAVES, P. M. B. Source: IBGE, 2014.

Source: the authors, 2019.

\subsection{Data gathering and analysis}

A case study was conducted adopting a quantitative and qualitative approach and data gathering took place in the period between November 2018 and April 2019 by means of semi-structured interviews, ethnobotanical walks, demonstrations of culinary recipe preparation, and participant observation as the ethnographic tool.

The interviewee sample was formed by theoretical saturation (FONTANELLA; RICAS; TURATO, 2008; FONTANELLA, et al., 2011). It consisted of 30 residents of São João da Chapada responsible for children and adolescents associated to the Walking Together Project (Projeto Caminhando Juntos - Procaj), an organization carrying out child and adolescent integral protection actions in that locality. In the other stages of data gathering, members of the community interested in the theme participated as well. Analysis adopted a qualitative descriptive approach (LÜDKE; ANDRÉ, 1986), content analysis (BARDIN, 2011) and descriptive statistics. The samples of plant material collected were deposited in the DIAM Herbarium at the Federal University of the Jequitinhonha and Mucuri Valleys (UFVJM).

The study was part of a broader research project entitled "Sociobiodiversidade e espaço social alimentar: conhecimento tradicional sobre plantas alimentícias no Vale do Jequitinhonha, 
MG" (Socio-biodiversity and Food Social Space: traditional social knowledge of food plants in the Jequitinhonha Valley) duly approved by the Research Ethics Committee of the Federal University of the Jequitinhonha and Mucuri Valleys (UFVJM) under protocol №92832418.6.0000.5108 and registered in the National System for the Management of the Genetic Heritage and Associated Traditional Knowledge (Sistema Nacional de Gestão do Patrimônio Genético e do Conhecimento Tradicional Associado), registration № A65D159.

\section{RESULTS AND DISCUSSION}

\subsection{Socio-economic aspects}

São João da Chapada is a district of the municipality of Diamantina divided into four sectors, two urban and two rural, for Census purposes, with a total population of 1,581 inhabitants (IBGE, 2010a). Although the Census defines two sectors of São João as Rural, the predominant milieu is that of a 'peasant population' in the socio-cultural sense of the term as Woortmann (1990) defines it, not in the economic or production sense. Furthermore, it is characterized by a Quilombola ethnicity with the presence of a Quilombola community in the district known as the Quartel do Indaia where many of the participants in the study grew up and where they have strong bonds of kinship and friendship and eventually they may collect or receive food plants from that locality. In 2019 the district self-recognized itself as a Quilombla community that includes the main residential center and the various other hamlets. The community is now awaiting the issuing of the corresponding certificate of recognition by the Palmares Foundation (Fundação Palmares) (KOLPING, 2019).

The original settlement of Diamantina and the surrounding areas was strictly associated to mining that began in the $18^{\text {th }}$ century and attracted a huge populational contingent to the region (MACHADO FILHO, 1980). As the mining work depended on the labor of enslaved Negroes, the greater part of the population of São João da Chapada was made up of enslaved or freed Negroes (MACHADO FILHO, 1985). Today, the population of the district of São João da Chapada continues to have a high proportion of Negroes (31.18\%) compared to the city of Diamantina (12.05\%) and the Brazilian population as a whole (7.61\%) (IBGE, 2010b). Among the interviewees of this study, the proportion of Negroes is even higher; $60 \%$ of the people are Negroes, $33.33 \%$ are mixed/brown-skinned and $6.67 \%$ are white. That ethno-racial profile is also influenced by the fact that the interviewees are participants in the Procaj because they are in social vulnerability, an indication which, in Brazil, is directly related to the Negro population (IPEA, 2017).

Study participants are in the 17 to 72 age group (Average age $=41$; Median=39; Standard Deviation=14.71). Most of them $(66.57 \%)$ have completed lower or higher secondary education. Altogether, $43.33 \%$ of them declared that they were housewives and did not mention other activities although it was observed that some of them engage in agro-extractive activities as well. Most of the families have an income of less than one official minimum salary and $40 \%$ of them have an income of less than half a minimum salary. The Bolsa Familia (Family Allowance) Program makes an expressive contribution 
to family incomes insofar as $53.33 \%$ of the families participate in the program and for $20 \%$ of the total number of families, that is their only income.

Gender was not set as a criterion for participation in the interviews but only women actually participated because they are responsible for the families' food. That is a characteristic associated to peasant cultures whereby gender relations are fundamental in the family unit's production organization (BIASE, 2010). Women's participation predominates in this type of research into plants because it is the women who take responsibility for the domestic and care universe (VASCONCELOS, 2001).

\subsection{Food Social Space}

\subsubsection{The food system}

In his work Poulain (2004) discusses how food, from the moment of its initial production to its arrival on the consumer's table, has a trajectory in which it is involved in flows, stages of transformation and has connections with various interconnected social spaces which, altogether, configure the Food Systems.

The socio-anthropological perspective makes it possible to expand understanding of that trajectory insofar as it includes in the aspect of those responsible for obtaining and preparing food and also includes the food eaters. "At each stage of the food system, social actors mobilize not only technological knowledge but also, representations to construct their decisions and drive the food onward towards the consumer [...]" (POULAIN, 2004, p. 253).

The diagram displayed in Figure 2 represents part of the food system in São João da Chapada within the framework of this study's intentions. It should be stressed that local food and feeding is centered on the domestic space and that the non-domestic supply channels and food preparation were secondary objects in this study. 
Figure 2 - Diagram of the São João da Chapada food system

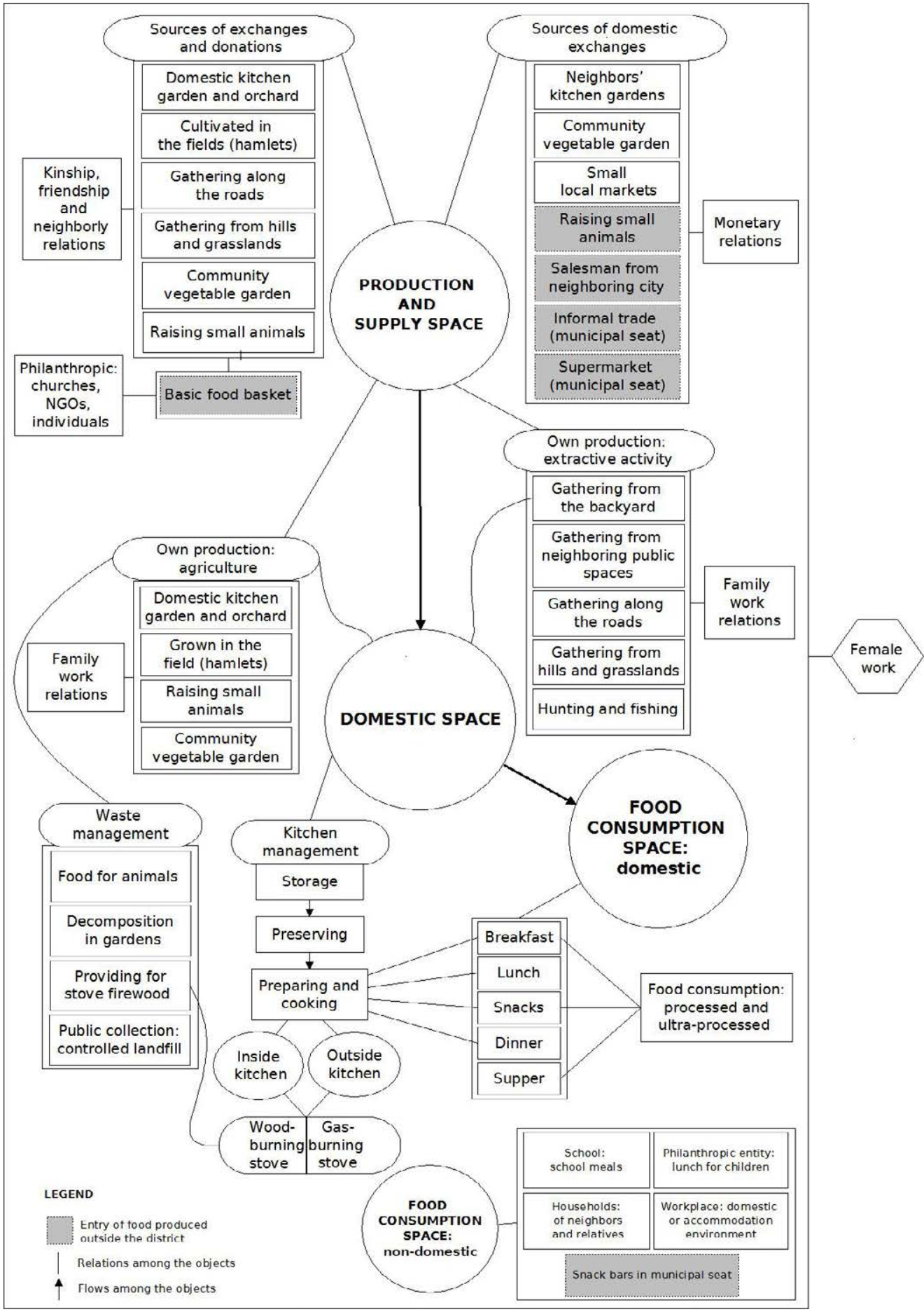

Source: the authors, 2019. 
Female labor is responsible for the management of the spaces and for the various stages of the food system in question (Figure 2). The male contribution to this food system consists mainly in financial contributions that enable the domestic purchases in the production and supply space in addition to extractive activities and gathering firewood.

The production and supply space embraces three categories: own production (agriculture, livestock raising and extractive activities) operated through family labor relations; exchanges and donations operated via kinship, friendship, and neighbor and philanthropic relations and domestic purchases operated by monetary relations. Local production is present in various input channels endowing the food culture with identifying traits related to socio-biodiversity. Beyond their food production and supply aspects, the backyards play a central role in community sociability.

In turn, the gathering of plants, especially the native species in the non-domestic spaces, is part of the traditional extractive activity which is "frequently associated to the fundamental axes of sustainable development, to local history and culture, to social aspects and to territoriality" (SARAIVA, 2009, p. 5).

Trading and donating the excess production of the domestic kitchen gardens among neighbors and family members mainly involve the leafy garden products. Exchanges involving food items, in the Maussian concept, constitute the reciprocity of the donation (MAUSS, 1974), whereby the social actors have a positive interaction engendered by their bonds of mutual indebtedness which preserves and strengthens their social relations.

At the Procaj headquarters in São João da Chapada there is a community kitchen/ market garden in which 14 of the 30 interviewed women (46.7\%) participate. That activity contributes towards food and nutrition security and complements their income. It also results in benefits associated to sociability and mental and physical health which was apparent in the declaration of one interviewed participant "my goodness, every day I am grateful for our little plant beds here; they have saved my life. Things have not been easy for me; working here [in the Procaj] has helped me so much". The production of the community market garden is traded with the local people (Figure 2) and with the Diamantina municipal authority to be used in the school meals program. Whatever is left over is shared out among the women responsible for each plant production bed.

From the production supply space, the products proceed to the domestic space in accordance with the community's techniques, knowledge, preferences and access possibilities, in addition to the local environmental conditions. Those two spaces intersect because agricultural own production occurs in the domestic spaces for $93.3 \%$ of the interviewees who also produce in other locations. In the case of own production by means of plant extrativism, it takes place in the domestic sphere but also in the public spaces nearby the residence such as roads, other hamlets, hills, and grasslands. The spontaneous plants are the products of own production and there are approximately the same number of species collected in the domestic space as there are in the non-domestic space.

In addition to the own production part, the management of the kitchen involving the stocking, preservation, preparation and cooking of the foodstuffs occurs in the domestic space. 
In our analysis we included the management of food residues not foreseen in the food system of Poulain (2004). That management fosters feedback for the system insofar as it reintroduces biomass and nutrients in the own production and in the management of the kitchen itself with the provision of material for the firewood stove.

Lastly, food arrives for the consumers in the domestic food consumption space, which is typified by its commensality, that is, by the act of everybody eating together which shows that it is the result of social and cultural identity interactions (POULAIN, 2004). In the non-domestic food consumption space, the food actions mainly refer to school meals and meals that social projects provide for children.

\subsubsection{The culinary space}

Work in the culinary space of São João is also essentially feminine and it is the space in which women and mothers have the greatest power in the face of the family; it is one of the elements of compensation for, and resistance to patriarchy given that "the women also have powers, delegated or not, that they take advantage of, notably in the domestic sphere, where they root their influence [...]" (SOIHET; SOARES; COSTA, 2001, p. 21).

All the houses except one have a kitchen inside the main building with a woodburning stove and $90 \%$ of them also have a gas-fired stove which they use mostly for quick preparations such as coffee and rice, and to use the oven. The preference for the wood stove is because of the flavor it endows the food with and because of the high price of bottled gas. The wood stove also has the advantage of warming the house, keeping water hot for household consumption and burning off some of the household waste.

Perishable food is stored in refrigerators in $96.7 \%$ of the homes but preservation techniques such desiccation to preserve meats, immersion in oils and the preparations of conserves of vegetables pickled in vinegar or brine are also used. The main spaces for lunches and dinners are the kitchen and the living room but other food consumption moments can take place in various other domestic spaces and even in the yard or on the pavement of the house.

\subsubsection{The eatables space}

Entering the eatables space means understanding what is considered to be food among the available resources. Given this study's focus on food of plant origin, the understanding of eatables space was restricted to that category.

Participants cited 178 plant species that they consumed of which 157 were mentioned during the interviews and 21 only in the ethno-botanical walks and participant observation. There was considerable variation (343.5\%) in the numbers of plants each participant mentioned. The lowest number mentioned was 23 and the highest, 102. Various factors could explain that difference including the influence of the domestic kitchen gardens on food patterns, the daily round of the individual interviewee, the degree of interest in participating and the person's ability to remember.

Of the plants cited in the interviews $(n=157)$, only $23.6 \%$ are consumed by at 
least half of the participants and $34.8 \%$ of the plant species were only mentioned by one or two interviewees. It is evident that the participants' consumption of such plants is centered on a small group of species.

For most of the plant species $(60.1 \%)$, the fruit is the edible part whereas for $27.5 \%$ it is the leaves, $7.3 \%$ the stem, $3.9 \%$ the roots, $2.2 \%$ the flowers and $1.1 \%$ the shoots. For some of the species $(2.2 \%)$, the edible part was not identified and others had more than one part that was consumed.

In the case of the spontaneous plant species the fruit was also the most consumed part $(61,5 \%)$ and they constitute the greater part of the variety of plants consumed albeit they are not part of the main meals, showing that they have a secondary role as food. The second most commonly consumed part of the spontaneous species is the leaves $(28.2 \%)$ and other parts are used very little.

The same pattern of consumption centered on only a few species observed for food of plant origin in general was repeated in the case of the spontaneous species (Table 1). 10 species $(12.8 \%)$ were consumed by more than half of the participants while $41 \%$ of the species were only mentioned by one or two of the interviewees.

Table 1 - Spontaneous plant species with citation frequency over $50 \%$

\section{Local Common name}

(Port.) (Eng.)

\section{Gabiroba}

(Guabiroba)

Samambaia

(Bracken fern)

Araçá

(Wild guava)

Palma dos infernos

(Drooping prickly pear)

Pequi

(Pequi or souari nut)

Côco indaiá

Indaia Palm)

Serralha

(Sow thistle)

Jabuticaba do mato

(Wild jabuticaba)

Picão/carrapicho

(Black-jack or cobblers pegs)

Jurubeba
Frequency (\%)

Campomanesia cf. sp.

90.0

Pteridium aquilinum (L.) Kuhn

86.7

Psidium sp.

Opuntia monacantha (Willd.) Haw.

Caryocar brasiliense Cambess.

Attalea sp.

Sonchus oleraceus L.

Plinia sp.

Bidens pilosa L.

Solanum paniculatum L.

50.0

Source: the authors, 2019. 
The taioba (Xanthosoma taioba E.G. Gonç.) and the and the ora-pro-nóbis (Pereskia aculeata Mill.) were not frequently cited but participant observation revealed considerable consumption of, and preference for those two plants.

Participants classified as 'spontaneous', $43.8 \%(n=78)$ of the plants they consumed (Table 2) and most of the species are considered to be Non-conventional Food Plants (KINUPP; LORENZI, 2014).

Some of the cited species were not identified because they were not found for collection being either out of season or naturally scarce.

Table 2 - Spontaneous plants consumed by the participants

\begin{tabular}{|c|c|c|}
\hline Botanical Family & $\begin{array}{l}\text { Local and Scientific names [Common name in } \\
\text { English] }\end{array}$ & Edible parts \\
\hline Amaranthaceae & $\begin{array}{l}\text { Espinafre (Spinacia oleracea L.) [Spinach], caruru } \\
\text { (Amaranthus sp) }\end{array}$ & Leaves \\
\hline Annonaceae & $\begin{array}{l}\text { Araticum (Annona sp.1) [Araticum], araticum } \\
\text { (Annona sp.2), araticum (Annona sp.3), araticum do } \\
\text { mato (Annona sp.4), ata (Annona sp5.), fruto do conde } \\
\text { (Annona sp.6), panã (Annona sp.7) [names include: } \\
\text { sugar apple, monkey apple sweet sop] }\end{array}$ & Fruits \\
\hline Apiaceae & $\begin{array}{l}\text { Agrião (Apium nodiflorum (L.) Lag.) [Fool's water- } \\
\text { cress] }\end{array}$ & Leaves \\
\hline Apocynaceae & Mangaba (Hancornia speciosa Gomes) [Mangabeira] & Fruits \\
\hline Araceae & Taioba (Xanthosoma taioba E.G. Gonç.) [Taioba] & Leaves \\
\hline Arecaceae & $\begin{array}{l}\text { Côco indaiá (Attalea sp.) [Indaia palm], licuri (Syagrus } \\
\text { cf. coronata (Mart.) Becc.) [Licuri palm], coquinho } \\
\text { do campo (Syagrus sp1.) [Palm tree sp.], côco da serra } \\
\text { (Syagrus sp2.) [Palm tree sp.] }\end{array}$ & Fruits \\
\hline Asteraceae & $\begin{array}{l}\text { Serralha (Sonchus oleraceus L.) [Sow thistle], dente de } \\
\text { leão (Taraxacum officinale F.H. Wigg.) [Dandelion], } \\
\text { picão (Bidens pilosa L.) [Black jack, Cobblers pegs], } \\
\text { gondó (Erechtites valerianifolius (Link ex Spreng.) DC) } \\
\text { [Tropical burnweed], quitoco (Pluchea sagittalis (Lam.) } \\
\text { Cabrera), assapeixe (Vernonia tweediana Baker.) }\end{array}$ & Leaves \\
\hline Bromeliaceae & $\begin{array}{l}\text { Ananás (Ananas ananassoides (Baker) L.B.Sm.) } \\
\text { [Dwarf pineapple] }\end{array}$ & Fruit \\
\hline Cactaceae & $\begin{array}{l}\text { Palma dos infernos (Opuntia monacantha (Willd.) } \\
\text { Haw.) [Drooping prickly pear], quiabo da serra (Ci- } \\
\text { pocereus minensis (Werderm.) Ritter), ora-pro-nóbis } \\
\text { (Pereskia aculeata Mill.) [Rose cactus, Blade-apple } \\
\text { cactus, Barbados gooseberry] }\end{array}$ & $\begin{array}{l}\text { Cladode } \\
\text { (palma), stem } \\
\text { (quiabo), leaf } \\
\text { (ora-pro-nóbis) }\end{array}$ \\
\hline
\end{tabular}




\begin{tabular}{|c|c|c|}
\hline Caryocaraceae & $\begin{array}{l}\text { Pequi (Caryocar brasiliense Cambess.) [Pequi, Souari } \\
\text { nut] }\end{array}$ & Fruit \\
\hline Costaceae & Cana de macaco (Costus sp.) & Leaves \\
\hline Crassulaceae & $\begin{array}{l}\text { Bálsamo (Sedum dendroideum Moc. \& Sessé ex DC) } \\
\text { [Tree stonecrop] }\end{array}$ & Leaves \\
\hline Curcubitaceae & São Caetano (Momordica charantia L.) [Bitter melon] & Fruit \\
\hline $\begin{array}{l}\text { Dennstaedtia- } \\
\text { ceae }\end{array}$ & $\begin{array}{l}\text { Samambaia (Pteridium aquilinum (L.) Kuhn) [Bracken } \\
\text { Fern] }\end{array}$ & Shoots \\
\hline Lamiaceae & Azeitona (Vitex sp.) & Fruit \\
\hline Lauraceae & $\begin{array}{l}\text { Sassafrás (Ocotea cf. odorifera (Vell.) Rohwer) [Bra- } \\
\text { zilian Sassafras], lobo-lobô (Persea rufotomentosa Nees } \\
\& \text { Mart.) }\end{array}$ & $\begin{array}{l}\text { Leaf (sassafrás) } \\
\text { and bark (boths) }\end{array}$ \\
\hline Malpighiaceae & $\begin{array}{l}\text { Murici (Byrsonima sp1.), murici (Byrsonima } \mathrm{sp} 2 .) \text {, } \\
\text { murici de árvore (Byrsonima sp3.) }\end{array}$ & Fruits \\
\hline Malvaceae & Malva (Malva cf. sylvestris L.) [Mallow] & Leaves \\
\hline $\begin{array}{l}\text { Melastomata- } \\
\text { ceae }\end{array}$ & $\begin{array}{l}\text { Quaresmeira roxa (Tibouchina sp.) [Glory Bush], cabe- } \\
\text { lo de nego (Mouriri sp.), canela de velho (Miconia sp.), } \\
\text { bosta de urubu (Miconia sp.) }\end{array}$ & $\begin{array}{l}\text { Flower (quares- } \\
\text { meira) and fruit } \\
\text { (the others) }\end{array}$ \\
\hline Moracea & Amora (Morus nigra L.) [Black Mulberry] & Fruits \\
\hline Myrtaceae & $\begin{array}{l}\text { Jabuticaba (Plinia cauliflora (Mart.) Kausel) [Jabuti- } \\
\text { caba, Brazilian grapetree], jabuticaba do mato (Plinia } \\
\text { sp.) [Wild Jabuticaba], goiaba (Psidium guajava L.) } \\
\text { [Guava], gabiroba (Campomanesia cf. sp.1), gabiroba } \\
\text { (Campomanesia cf. sp.2), gabiroba de árvore (Campo- } \\
\text { manesia cf. sp.3), gabiroba do mato (Campomanesia cf. } \\
\text { sp.4), } \\
\text { Campomanesia 1,2,3, } 4 \text { [Guabiroba] } \\
\text { café são josé (Eugenia sp.), araçá (Psidium sp.1), araçá- } \\
\text {-pedra (Psidium sp.2), araçá do carrasco (Psidium sp.3), } \\
\text { jambo (Syzygium sp.), pitanga (Eugenia uniflora L.) } \\
\text { [Surinam cherry], limãozinho, caboclo }\end{array}$ & Fruits \\
\hline Phytolaccaceae & $\begin{array}{l}\text { Chifre de veado (Phytolacca cf. thyrsiflora Fenzl. ex } \\
\text { J.A.Schmidt) }\end{array}$ & Leaves \\
\hline Piperaceae & Capeba (Piper umbellatum L.) & Leaves \\
\hline Plantaginaceae & $\begin{array}{l}\text { Transagem (Plantago major L.) [Broad-leaved Plan- } \\
\text { tain] }\end{array}$ & Leaves \\
\hline Poacea & Bambu [Bamboo] & Shoot \\
\hline Portulacaceae & Beldroega (Portulaca oleracea L.) [Purslane] & Leaves \\
\hline
\end{tabular}




\begin{tabular}{|c|c|c|}
\hline Rosaceae & $\begin{array}{l}\text { Amora do mato (Rubus sellowii Cham. \& Schltdl), } \\
\text { moranguinho (Rubus rosifolius Sm.) [Mauritius Rasp- } \\
\text { berry], ameixa (Eriobotrya japônica (Thunb.) Lindl.) } \\
\text { [Loquat] }\end{array}$ & Leaves \\
\hline Rubiacea & Marmelada (Cordiera sessilis (Vell.) Kuntze) & Fruit \\
\hline Solanaceae & $\begin{array}{l}\text { Jurubeba (Solanum paniculatum L.), juá (Physalis cf. } \\
\text { pubescens L.) [Husk tomato] }\end{array}$ & Fruit \\
\hline Unidentified & Cabo jantar & Fruit \\
\hline Not collected & $\begin{array}{l}\text { Agrião do brejo, angélica, bacupari, caju do mato, } \\
\text { caqui do mato, maminha de vaca, quiababá and sapê }\end{array}$ & Leaves and fruits \\
\hline
\end{tabular}

Source: the authors, 2019.

The plants are mostly consumed in natura, but the leaves are more commonly prepared as sautés. Most of the fruits are native fruits collected in places further away from the houses and consumed without delay. Their consumption is associated to leisure and they are seen as a complement to the main diet. Leaves are mostly taken from introduced species and are picked in the domestic space shortly before they are consumed. They are prepared together with the species cultivated in the kitchen gardens before and in the words of one participant, "when the greens in the garden are a bit short, I pick all these wild plants to complement them; they are not just useless bush, we eat them". In regard to the shoots of bamboo and bracken ferns, it is quite common to see them pickled in brine.

Souza (2018) conducted a study of agro-biodiversity in the Quilombola community of Raiz located 51 kilometers away from Diamantina, in the municipality of Presidente Kubitschek. The study listed 83 species of edible plants, 70 of which (84.3\%) were also encountered in the present study. Those results express the socio-biodiversity present in the food culture of the traditional communities in the Espinhaço Range.

\subsubsection{The space of food consumption habits}

The semi-structured interviews made use of the 24-hour dietary recall method, whereby the interviewee reported all the food items consumed in the preceding 24 hours (FISBERG; MARCHIONI; COLUCCI, 2009), and an analysis was made of the food cupboard contents listing all the food items present in the person's home at the time of the interview (ALBUQUERQUE; LUCENA; ALENCAR, 2010). The results obtained with those two approaches are organized into two different timeframes in the subsections that follow.

\subsubsection{The one-day food portrait}

On average the interviewees ate something four times a day and most of them had lunch in the day and dinner in the evening. Apart from those meals dedicated to ingesting more substantial food it was common for them to drink coffee throughout the 
day, always sweetened. Coffee has an expressive role in the everyday lives of the families and it is consumed in all the homes, fostering moments of pause and social interaction among family members and neighbors as well as being taken for its effects as a stimulant.

Breakfast is hardly diversified at all and is mainly based on the consumption of coffee sweetened with crystallized sugar and accompanied by ultra-processed biscuits (38.5\%). Other foods consumed less frequently, include cake (11.5\%), cheese $(11.5 \%)$ and bread (7.7\%). 30.8\% of the interviewees said that they took coffee alone for breakfast and the next food they would eat would be four hours later at lunch time. Some participants, especially the older ones reported that they had become accustomed to that practice because of the routine of the agricultural work they used to do.

For most (87\%), the lunches and dinners contained rice and beans and other accompaniments mentioned included angu (a thick cooked mass of maize), potatoes, cassava and spaghetti. Five of the interviewees declared that for lunch they had rice and beans alone. That lack of diversity was observed at all the other times that the same participants consumed food.

Meat and animal fats were present in $83.3 \%$ of the meals - pork $(33.3 \%)$, beef (29.6\%), chicken (18.5\%), and fish (3,7\%). There were drinks, mostly natural fruit juices to accompany $22.2 \%$ of the lunches and dinners but dessert was only registered by $13 \%$.

Vegetables and greens were consumed in $66.7 \%$ of the lunches and dinners. In $35.2 \%$ of those meals there were cooked vegetables, in $22.2 \%$ sautéed greens and in $18.5 \%$ raw salads. The most consumed vegetables in order of frequency were potatoes, tomatoes, ora-pro-nobis, collard greens, pumpkin, okra and cabbage, respectively.

Food preparation makes use of vegetable oil (soybean) and lard and sometimes chicken fat is use as well. The option to use vegetable oil or animal fat is influenced by the recommendations of health workers and by the construction of 'taste', which Dória (2015) conceives to be the cultural derivative of palatability.

Snacks between meals are more diversified. In $50 \%$ of them coffee is taken and in $15.9 \%$ it is the only item. $18.2 \%$ of the interviewees eat fruits at snack times but none of the fruits cited was a spontaneous species. Other food items consumed were ultraprocessed biscuits (15.9\%), cake (11.4\%) and bread (6.8\%).

The least frequent of interviewees' meals is supper (20\%). Its composition is similar to that of the snacks.

The variety of plants mentioned in the general list $(n=178)$ presented in the preceding section is far greater than that informed in the 24-hour recall. In the latter only one spontaneous species was listed, ora-pro-nobis present in 3.9\% of the described meals, and there was only one cultivated species considered to be non-conventional, azedinha, present in $1.8 \%$ of the meals. That quantitative difference registered by the two methods is justified by the respective seasonal and temporal limitations imposed on the 24-hour recall method and also by people's tendency to consider all the plant species they know of including those that they do not, in fact, consume, or because they do not recall it or did not consider the plants they eat in the yard or between the main meals in the 24-hour 
inventory or simply because the consumption of some species is waning.

\subsubsection{The Food in the Cupboard}

The average number of items listed by the food cupboard analysis method was 25 $($ Median $=26$, Standard Deviation $=8.3$ ) and the food items most identified were spaghetti and rice both with a citation frequency of $96.7 \%$ There was a visible similarity with the results of the 24-hour recall registration insofar as all the items listed in the food cupboard inventory by $50 \%$ of the participants were present in the 24-hour registration.

Among the food items that were present in the food cupboards of $60 \%$ of the interviewees are those that are part of the official Brazilian Basic Food Basket (BRASIL, 1938; DIEESE, 2016) along with some minimally processed foods. Although no one mentioned cassava (manioc) meal it was actually present in $80 \%$ of the food cupboards showing that it is important in the local food culture.

Greens and vegetables are the most diversified group of food items but at the same time their frequencies of mention were very low, indicating a dispersion in consumption patterns. Most of the of the 44 fruit, vegetable and greens species cited were purchased. Among the plants considered to be non-conventional, three were cultivated - maxixe, tarracha and fava - and four were spontaneous - bracken fern, souari nut, indaia palm and husk tomato. Considering that most of the houses have a kitchen garden and an orchard, various vegetables that are only harvested when they are needed may not be in the food cupboard.

Most of the processed foods mentioned are produced by the interviewees themselves and among them are regional foods such as caramelized milk, pumpkin, green papaya and orange jams, and jabuticaba jelly. Outstanding are the spontaneous plants conserved as pickles, namely, fern shoots and bamboo shoots.

In $43.3 \%$ of the households there were cracker-type biscuits in keeping with the citation in the 24-hour recall analysis. The strong presence of that snack in the food cupboards is related to the transition from homemade food items like cakes, rusks, bread, and porridges to the consumption of ultra-processed foods. Dittz (2018) reported a similar transition in a food system research study in rural neighborhoods of the municipality of Serro, which borders on Diamantina.

Other ultra-processed foods are present in the household food cupboards. The study participants state that their access to that kind of food is recent and it represents their participation in the consumer market and their family success. That social significance attributed to consuming ultra-processed food products should be analyzed to achieve the reduction in the consumption of that group of products that the Food Guide for the Brazilian Population (BRASIL, 2014) has as goal.

\subsubsection{Food temporality}

The perception of spontaneous food plants' seasonality is not universal among the study participants and commonly they are unaware of the time of year when the ed- 
ible parts of such species are available. Participants more involved in cultivation show greater knowledge of that aspect especially in regard to drooping prickly pear, bamboo and ferns. That may be because of personal preference and use or because they were in season around the time of the interviewing.

In the course of the year, the food that is consumed is influenced by the visits of relatives. On such occasions it is common to prepare those non-conventional plant foods that the visitors would not normally have access to in other places. Apart from that some products such as pickled fern and bamboo shoots are traded.

The living experiences of the different generations differentiate the food habits by age groups. Children and young people are less fond of plant food consumed in natura especially the spontaneous plant species identified in this study and that characteristic has been registered for other communities (ALBUQUERQUE, 2014). On the other hand, adults and old people make greater use of them and some participants attribute that difference to the context of scarcity in which they grew up where there was little choice of what you could eat. Nowadays there is easier access to the items of the Basic Food Basket reflected in remarks such as "no more running out of rice and beans".

Underlying those generational differences in food preferences is the transformation of the culture as a whole. There is negation of the place of origin because it is considered to be out of date and that is reflected in the food habits, especially in the increased consumption of ultra-processed foods.

\subsubsection{The social differentiation space}

The participants have a positive opinion regarding their families' food situation, most of them declaring it to be 'good' or 'reasonable'. However, those declarations are inconsistent with others in which they comment on how hard it is to get food and other basic consumption items.

There is social differentiation apparent in the temporal relations between a needy past and a present with basic supply. Many São João residents associate the diet on the past, based on own production and on preparations of maize, pork fat and various spontaneous plant species - sow thistle, tropical burnweed, bracken fern, drooping prickly pear - with poverty whereas the present day diet based on purchased food like rice, beans and some ultra-processed products is associated with social ascension. As one participant put it:

When I was a girl, my mother used to leave a pot of rice on top of the stove, but not for us to eat, it was so that if anyone came by they would think that we were not in need. Today our life is better, we don't need to go through that anymore, we have rice that is 'truly' to eat.

The relations of social differentiation are established in the coexistence of a negative remembrance of hunger and scarcity, especially regarding the plants consumed in the mid-day and evening meals which represent the family's under-supply of food, and a positive memory of childhood and family bonds especially associated the fruits eaten at 
snack times which represent moments of sociability, leisure and delight.

The contact between the local foods culture and the food practices of groups with other identities and/or of other social classes demarcates another social differentiation whereby the food consumed by external groups is classified as being healthier than the local food.

\section{CONCLUSIONS}

Knowledge and practices associated to spontaneous food plants present in the community's territory, in common with Non-conventional Food Plants in general, are constitutive of local food culture in São João da Chapada. Although it is clear that a reduction in the consumption of such species is in course, especially because of enhanced access to processed and ultra-processed foods and the reconfiguration of agro-extractive work which has been gradually reducing with the increase of service provision. That change in food habits is expressed in a process of deterritorialization.

The study results can subsidize actions designed to foster food and nutrition security support through the reinstatement, valorization and strengthening of traditional knowledge. To that end, stimulating the consumption of spontaneous plants should take into account the dominance of female labor in the local food system and it should be integrated to other actions promoting Food and Nutrition Security (FNS) such as ensuring access to the basic rights - health, education, housing, work - respecting the local culture and valuing people's human dignity. It is important to promote agro-ecological food production systems for the cultivation and harvesting of those plant resources. Just like the spontaneous plants, the cultivated non-conventional foods plants and all the other foods of plant origin are extremely important for effectuating FNS in rural communities like São João da Chapada. Even though the consumption of spontaneous plant species offers various advantages, it must be acknowledged that there is rejection of some food items that were much consumed during their childhood and adolescence by some community members. To enhance understanding of the food social space in question, future research efforts could include the roles of other social agents like the State, the third sector and the media. It is also necessary to expand the list of spontaneous food plants and their uses.

\section{Acknowledgements}

Thanks go to the Caminhando Juntos Project (PROCAJ) and especially to the São João da Chapada community.

\section{References}

ALBUQUERQUE, U. P.; LUCENA, R. F. P.; ALENCAR, N. L. Métodos e técnicas para coleta de dados etnobiológicos. In: ALBUQUERQUE, U. P.; LUCENA, R. F. P.; CUNHA, L. V. F. C. (Eds.). 
Métodos e técnicas na pesquisa etnobiológica e etnoecológica. Recife: Núcleo Publicações em Ecologia e Etnobotânica Aplicada (NUPEEA), 2010.

ALBUQUERQUE, U. P. et al. Methods and Techniques Used to Collect Ethnobiological Data. In: Methods and Techniques in Ethnobiology and Ethnoecology. New York: Springer, 2014. p. $15-37$.

BARDIN, L. Análise de conteúdo. São Paulo: Edições 70, 2011.

BIASE, L. A articulação entre o campesinato e agroecologia: espaços femininos e masculinos. Cadernos de Campo, n. 1, p. 177-200, 2010. Available at: < http://seer.fclar.unesp.br/cadernos/ article/download/5144/4219>. Accessed on: March 8, 2019.

BRAGA, V. Cultura alimentar: contribuições da antropologia da alimentação. Saúde em Revista, Piracicaba, v. 6, n. 13, p. 37-44. 2004. Available at: http://plataforma.redesan.ufrgs.br/ biblioteca/pdf_bib.php?COD_ARQUIVO=3387. Accessed on: March 3, 2019.

BRASIL. Decreto-Lei no 399 de 30 de abril de 1938. Available at: < https://www2.camara.leg. br/legin/fed/declei/1930-1939/decreto-lei-399-30-abril-1938-348733-publicacaooriginal-1-pe. html>. Accessed on: May 23, 2019.

BRASIL. Ministério do Meio Ambiente. Serra do Espinhaço. [2005?]. Available at: < http:// www.mma.gov.br/images/arquivo/80252/FichasRBs/Serra_do_Espinhaco-es_AT.pdf $>$. Accessed on: March 7, 2019.

BRASIL. Ministério do Desenvolvimento Agrário, Ministério do Meio Ambiente, Ministério do Desenvolvimento Social e Combate à Fome. Plano Nacional de Promoção das Cadeias de Produtos da Sociobiodiversidade. Brasília: DF, 2009. Available at: < https://bibliotecadigital. seplan.planejamento.gov.br/bitstream/handle/123456789/1024/Plano\%20Sociobiodiversidade. pdf? sequence $=1$ \&isAllowed $=y>$. Accessed on: February 6, 2019.

BRASIL. Ministério da Saúde. Secretaria de Atenção à Saúde. Departamento de Atenção Básica. Guia Alimentar para a População Brasileira. 2. ed. Brasília: Ministério da Saúde, 2014. Available at: <http://bvsms.saude.gov.br/bvs/publicacoes/guia_alimentar_populacao_brasileira_2ed. pdf $>$. Accessed on: January 23, 2019.

DIEESE - Departamento Intersindical de Estatística e Estudos Socioeconômicos. Metodologia da Pesquisa Nacional da Cesta Básica de Alimentos. 2016. Available at: < https://www.dieese. org.br/metodologia/metodologiaCestaBasica2016.pdf>. Accessed on: January 04, 2019.

DITTZ, V. S. O sistema alimentar e a constituição de relações de trabalho híbridas e laços de solidariedade e parentesco no uso e produção do espaço rural. 2018. Dissertation (MSc in Rural Studies) - Universidade Federal dos Vales do Jequitinhonha e Mucuri, Diamantina, 2018. Available at: < http://acervo.ufvjm.edu.br/jspui/bitstream/1/2356/1/vitor_sousa_dittz.pdf >. Accessed on: April 02, 2019.

DÓRIA, C. A. O gosto, deriva cultural do paladar. Revista Latino Americana de Psicanálise, v. 13, n. 2, p. 163-167, 2015. Available at: < http://www.bivipsi.org/wp-content/uploads/Cali- 
ban_Vol13_No2_2015_-port_p163-167.pdf>. Accessed on: March 10, 2018.

FISBERG, R. M.; MARCHIONI, D. M. L.; COLUCCI, A. C. A. Avaliação do consumo alimentar e da ingestão de nutrientes na prática clínica. Arquivos Brasileiros de Endocrinologia e Metabologia, v. 53, n. 5, p. 617-624, 2009. Available at: < https://www.scielo.br/pdf/abem/v53n5/14. pdf >. Accessed on: November 04, 2017.

FONTANELLA, B. J. B.; RICAS, J.; TURATO E. R. Amostragem por saturação em pesquisas qualitativas em saúde: contribuições teóricas. Cadernos de Saúde Pública, Rio de Janeiro, v. 24, n. 1, p. 17-27, 2008. Available at: < https:/www.scielo.br/scielo.php?script $=$ sci arttext\&pid $=$ S0102-311X2008000100003 > . Accessed on: November 05, 2017.

FONTANELLA, B. J. B. et al. Amostragem em pesquisas qualitativas: proposta de procedimentos para constatar saturação teórica. Cadernos de Saúde Pública, Rio de Janeiro. v. 27, n. 2, p. 388-394, 2011. Available at: < https://www.scielo.br/scielo.php? script=sci_arttext\&pid=S0102$-311 X 2011000200020 \& \operatorname{lng}=\mathrm{en} \& n r m=\mathrm{iso} \& \operatorname{lng}=\mathrm{pt}>$. Accessed on: November 05, 2017.

IABS - Instituto Brasileiro de Desenvolvimento e Sustentabilidade. Reserva da Biosfera da Serra do Espinhaço - RSBE. Revista Reserva da Biosfera da Serra do Espinhaço, Brasília, v.1, n.1. 2017. Available at: <http://editora.iabs.org.br/site/wp-content/uploads/2018/03/RBSE-Vers\%C3\%A3o-final.pdf>. Accessed on: June 05, 2018.

IBGE - INSTITUTO BRASILEIRO DE GEOGRAFIA E ESTATÍSTICA. Censo demográfico 2010: sinopse por setores. 2010a Available at: <https://censo2010.ibge.gov.br/>. Accessed on: November 04, 2018.

IBGE - INSTITUTO BRASILEIRO DE GEOGRAFIA E ESTATÍSTICA. Censo demográfico 2010: SIDRA. 2010b. Available at: < https://sidra.ibge.gov.br/Tabela/3175>. Accessed on: June 09, 2019.

IPEA - Instituto de Pesquisa Econômica Aplicada. A Nova Plataforma da Vulnerabilidade Social: Primeiros resultados do Índice de Vulnerabilidade Social para a série histórica da Pnad (2011-2015) e desagregações por sexo, cor e situação de domicílio. Rio de Janeiro, 2018. Available at: <repositorio.ipea.gov.br/bitstream/11058/9477/1/A_nova_plataforma_da_vulnerabilidade_social.pdf $>$. Accessed on: February 18, 2019.

KINUPP, V. F. Plantas alimentícias não-convencionais da Região Metropolitana de Porto Alegre, RS. 2007. Thesis (PhD in Plant Science) - Universidade Federal do Rio Grande do Sul, Porto Alegre, 2007. Available at: < https://ume.ufrgs.br/bitstream/handle/10183/12870/000635324. pdf? sequence $=1$ \&isAllowed $=y>$. Accessed on: October 29, 2017.

KINUPP, V. F.; LORENZI, H. Plantas Alimentícias Não Convencionais (PANC) no Brasil: guia de identificação, aspectos nutricionais e receitas ilustradas. São Paulo: Instituto Plantarum de Estudos da Flora, 2014.

KOLPING. São João da Chapada se auto-reconhece como comunidade quilombola. 2019. Available at: < http://kolpingminasgerais.org.br/index.php/2019/11/21/sao-joao-da-chapada-se-auto-reconhece-como-comunidade-quilombola/>. Accessed on: November 29, 2019. 
LÜDKE, M.; ANDRÉ, M. E. D. A. Pesquisa em educação: abordagens qualitativas. São Paulo: E.P.U., 1986.

MACHADO FILHO, A. M. Arraial do Tijuco, cidade Diamantina. 3. ed. Belo Horizonte: Editora Itatiaia, 1980.

MACHADO FILHO, A. M. O negro e o garimpo em Minas Gerais. 3. ed. Belo Horizonte: Editora Itatiaia, 1985.

MAUSS, M. Ensaio sobre a dádiva. Forma e razão da troca nas sociedades arcaicas. In: Sociologia e antropologia. São Paulo: Edusp, 1974.

MONTEIRO, C. A. et al. A estrela brilha. World Nutrition, v. 7, n. 1-3, 2016. Available at: $<$ http://archive.wphna.org/wp-content/uploads/2016/02/WN-2016-7-1-3-28-40-Monteiro-Cannon-Levy-et-al-NOVA-Portuguese.pdf>. Accessed on: May 18, 2019.

POULAIN, J. P; PROENÇA, R. P. C. O espaço social alimentar: um instrumento para o estudo dos modelos alimentares. Revista de Nutrição, v. 16, n. 3, p. 245-256, 2003. Available at: < https://doi.org/10.1590/S1415-52732003000300002>. Accessed on: October 5, 2017.

POULAIN, J. P. Sociologias da alimentação: os comedores e o espaço social alimentar. Florianopólis: Editora da UFSC, 2004.

RIBEIRO, E. M. et al. Programas sociais, mudanças e condições de vida na agricultura familiar do Vale do Jequitinhonha Mineiro. Revista de Economia e Sociologia Rural, v. 52, n. 2, p. 365-386, 2014. Available at: <https://www.scielo.br/scielo.php?script=sci_arttext\&pid =S0103-20032014000200009>. Accessed on: May 18, 2019.

SARAIVA, N. A. Manejo sustentável e potencial econômico da extração do buriti nos lençóis maranhenses. 2009. Dissertation. (MSc in Sustainable Developmentação) - Universidade de Brasília, Brasília, 2009. Available at: < https://repositorio.unb.br/bitstream/10482/4168/1/2009 NicholasAllainSaraiva.pdf>. Accessed on: May 18, 2019.

SCHNEIDER, A. A. A Flora Naturalizada no Estado do Rio Grande Do Sul, Brasil: Herbáceas Subespontâneas. Biociências, Porto Alegre, v. 15, n. 2, p. 257-268, 2007.

SOIHET, R.; SOARES, R. M. A.; COSTA, S. G. A história das mulheres. Cultura e poder das mulheres: Ensaio de Historiografia. Gênero, Niterói, v. 2, n. 1, p. 7-30, 2001. Available at: < https://periodicos.uff.br/revistagenero/article/view/30986/18075>. Accessed on: May 18, 2019.

SOUZA, M. A. De lembrar, de ter e de comer. A cultura alimentar e a manutenção da agrobiodiversidade na comunidade Quilombola de Raiz. 2018. Dissertation (MSc in Rural Studies) - Universidade Federal dos Vales do Jequitinhonha e Mucuri, Diamantina, 2018. Available at: $<$ http://acervo.ufvjm.edu.br/jspui/bitstream/1/2022/1/marta_aguiar_souza.pdf $>$. Accessed on: March 08, 2019.

VASCONCELOS, E. M. Educação popular e terapia médica. In: SCOCUGLIA, A.C.; MELO NETO, J.F (Org.). Educação popular: outros caminhos. João Pessoa: Editora Universitária, 
2001. p. 123-134.

WOORTMANN, K. Com parente não se neguceia: o campesinato como ordem moral. Anuário Antropológico, Rio de Janeiro, n. 87, p. 11-73, 1990. Available at: < https://periodicos.unb.br/ index.php/anuarioantropologico/article/view/6389/7649>. Accessed on: March 08, 2019. 
Luiza Helena Pedra da Silva

$\checkmark$ luiza.pedra@gmail.com

ORCiD: https://orcid.org/0000-0001-6972-1429
Submitted on: 12/03/2021 Accepted on: 30/08/2021

2021;24e:00031

\section{Fabiane Nepomuceno Costa}

$\varangle$ fncosta@hotmail.com

ORCiD: https://orcid.org/0000-0002-0297-4226

\section{Nadja Maria Gomes Murta}

$\checkmark$ nadjamurta@gmail.com

ORCiD: https://orcid.org/0000-0003-3904-9808

How to cite: PEDRA DA SILVA, L. H.; COSTA, F. N.; MURTA, N. M. G. "Not just useless bush": food culture and spontaneous plants in the Jequitinhonha Valley, Minas Gerais/Brazil. Ambiente \& Sociedade. São Paulo, v. 24, p. 1-22, 2021. 


\title{
"Não é mato à toa": cultura alimentar e plantas espontâneas no Vale do Jequitinhonha, MG/Brasil
}

\author{
Luiza Helena Pedra da Silva \\ Fabiane Nepomuceno Costa \\ Nadja Maria Gomes Murta
}

São Paulo. Vol. 24, 2021

Artigo Original
Resumo: Os conhecimentos e práticas alimentares presentes no Vale do Jequitinhonha são resultados de sua sociobiodiversidade e sofrem impactos pelo processo de homogeneização alimentar. Esse estudo objetiva caracterizar o espaço social alimentar e o papel das plantas espontâneas na comunidade de São João da Chapada, em Diamantina (Minas Gerais/Brasil). Assim, pretende-se contribuir para o fortalecimento da cultura alimentar de comunidades rurais. Com abordagem qualitativa e quantitativa foram realizadas entrevistas semiestruturadas, caminhadas etnobotânicas, demonstrações culinárias e observação participante. Realizou-se análise de conteúdo temática e estatística descritiva. Constata-se que o espaço social alimentar local é gerido pelo trabalho feminino e possui forte vínculo territorial. Foram identificadas 78 espécies de plantas espontâneas alimentícias. Essas plantas desempenham um papel simbólico, além do nutricional, e são importantes na cultura alimentar, apesar do conhecimento sobre elas ser superior ao uso efetivo.

Palavras-chave: Espaço social alimentar; Sociobiodiversidade; Plantas alimentícias não convencionais; Etnobotânica; Sistema alimentar.

Como citar: PEDRA DA SILVA, L. H.; COSTA, F. N.; MURTA, N. M. G. "Não é mato à toa": cultura alimentar e plantas espontâneas no Vale do Jequitinhonha, MG/Brasil. Ambiente $\mathbb{\&}$ Sociedade. São Paulo, v. 24, p. 1-21, 2021. 


\title{
"No es hierba al azar": cultura alimentaria y plantas espontáneas en el Valle de Jequitinhonha, MG/Brasil
}

\author{
Luiza Helena Pedra da Silva \\ Fabiane Nepomuceno Costa \\ Nadja Maria Gomes Murta
}

São Paulo. Vol. 24, 2021

Artículo original
Resumen: Los conocimientos y las prácticas dietéticas en el Valle del Jequitinhonha son el resultado de su sociobiodiversidad y han sido impactados por el proceso de homogeneización alimentaria. Este estudio tiene como objetivo caracterizar el espacio social alimentario y el papel de las plantas espontáneas en la comunidad de São João da Chapada, en Diamantina (Minas Gerais/Brasil). La intención es contribuir para el fortalecimiento de la cultura alimentaria de comunidades rurales. Con un abordaje cualitativo y cuantitativo, se realizaron entrevistas semiestructuradas, caminatas etnobotánicas, demostraciones culinarias y observación participante. Se realizó análisis de contenido temático y estadística descriptiva. El espacio social alimentario local es gestionado por el trabajo femenino y posee un fuerte vínculo territorial. Se identificaron 78 especies de plantas alimenticias espontáneas. Esas plantas tienen un papel simbólico, además de nutricional, y son importantes para la cultura alimentaria, aunque el conocimiento acerca de ellas sea superior a su uso real.

Palabras-clave: Espacio social alimentario; Sociobiodiversidad; Plantas alimenticias no convencionales; Etnobotánica; Sistema alimentario.

Como citar: PEDRA DA SILVA, L. H.; COSTA, F. N.; MURTA, N. M. G. "No es hierba al azar": cultura alimentaria y plantas espontáneas en el Valle de Jequitinhonha, MG/Brasil. Ambiente $\&$ Sociedade. São Paulo, v. 24, p. 1-21, 2021. 